\title{
Linear atrophoderma of Moulin: a case report and review of the literature
}

\author{
Aikaterini Patsatsi, M.D. ${ }^{1}$, Aikaterini Kyriakou, M.D. MSc ${ }^{1}$, George Chaidemenos, M.D. ${ }^{2}$, \\ Dimitrios Sotiriadis, M.D. ${ }^{1}$
}

${ }^{1}$ Second Dermatology Department, Aristotle University School of Medicine, Papageorgiou Hospital, Thessaloniki, Greece

${ }^{2}$ Dermatology Practice, Thessaloniki, Greece

Key words: linear, atrophoderma, Moulin, linear scleroderma

Citation: Patsatsi A, Kyriakou A, Chaidemenos G, Sotiriadis D. Linear atrophoderma of Moulin: a case report and review of the literature. Dermatol Pract Conc. 2013;3(1):3. http://dx.doi.org/10.5826/dpc.0301a03.

Received: June 14, 2012; Accepted: November 25, 2012; Published: January 31, 2013

Copyright: $@ 2013$ Patsatsi et al. This is an open-access article distributed under the terms of the Creative Commons Attribution License, which permits unrestricted use, distribution, and reproduction in any medium, provided the original author and source are credited.

Funding: None.

Competing interests: The authors have no conflicts of interest to disclose.

All authors have contributed significantly to this publication.

Corresponding author: Aikaterini Patsatsi, M.D., Plagiari PO Box 461, 57500 Thessaloniki, Greece. Tel. +306944500285; Fax.

+302310991583. Email: katerinapatsatsi@gmail.com.

ABSTRACT Linear atrophoderma of Moulin is a rare, acquired, linear dermatosis. We present a 17-year-old girl with multiple asymptomatic brownish atrophic plaques in a zosteriform distribution on the left side of the trunk. Clinical presentation and dermatopathology was compatible with the diagnosis of linear atrophoderma. Twenty years after its initial description by Moulin, there are yet a limited number of case reports and unanswered questions regarding this entity.

\section{Case presentation}

A 17-year-old girl presented with a six-month history of multiple asymptomatic brownish atrophic plaques in a zosteriform distribution on the left side of her trunk (Figure 1). There was no family history of a similar skin disease. Laboratory studies were unremarkable for any chronic or autoimmune disorder. Biopsy of a lesion showed a normal epidermis with increased pigmentation of the basal layer and a broad dermis with thickened collagen fibers and diminished periadnexal and subcutaneous fat tissue (Figures 2, 3, 4).

Clinical and dermatopathologic findings were compatible with atrophoderma of Moulin. The use of topical steroids and tacrolimus as a second-line regimen did not result in any improvement of lesions.

\section{Discussion}

Linear atrophoderma is a rare, acquired, linear dermatosis. It is named after Moulin, who, in 1992, reported on five patients with pigmented and more or less atrophic bands along Blaschko's lines [1].

The age of onset in the first described cases ranged from 6 to 20 years. Lesions were unilateral, forming a recumbent "S" pattern, and the intensity of pigmentation and atrophy was variable. They remained stable throughout an observation period of 2 to 30 years. Of the skin biopsies performed on three patients, there was only irregular and moderate hyperpigmentation of the basal layer. In the dermis, there was no distinct pigment incontinence, no inflammation or alteration of connective tissue texture, and the clinical 


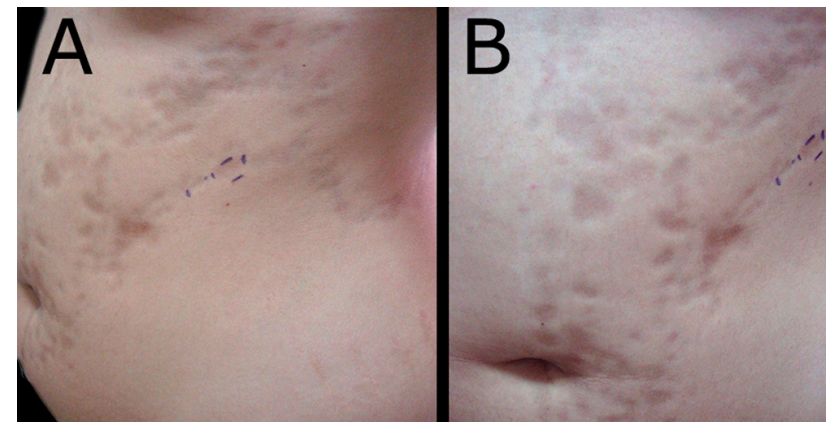

Figure 1. (A \& B) Atrophic plaques on the left side of the trunk. [Copyright: @2013 Patsatsi et al.]

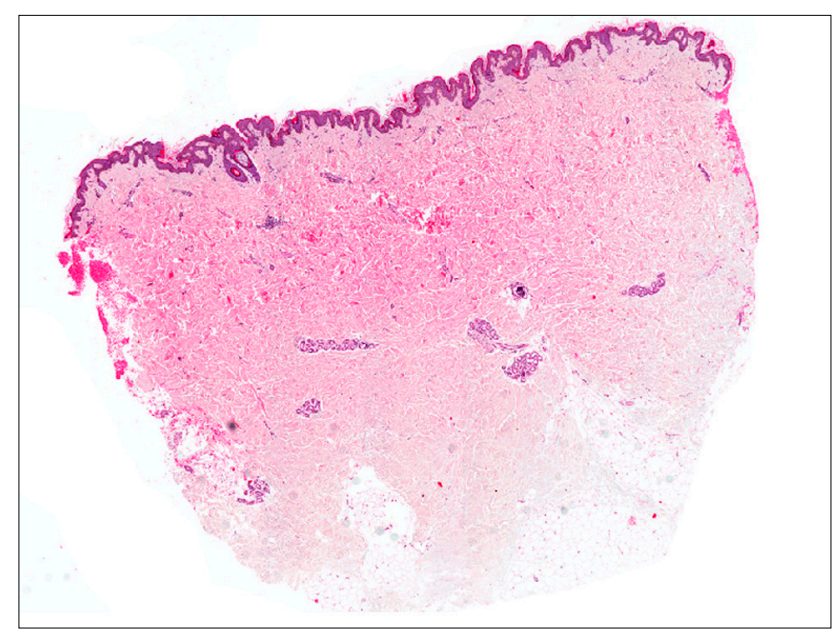

Figure 2. Normal epidermis and broad dermis. [Copyright: (C2013 Patsatsi et al.]

impression of skin atrophy was attributed to atrophy of the subcutaneous tissue [1].

Up to now there have been 30 reported cases of linear atrophoderma of Moulin [2-22]. In 2005, Ang et al mentioned that many cases of linear dermatoses were grouped under the umbrella of linear atrophoderma [23]. In Table 1,30 reported cases that resemble the initial description of linear atrophoderma of Moulin are listed.

Now, twenty years after the initial description of this entity, there are still some unresolved issues. The differential diagnosis of zosteriform or linear scleroderma is not clear clinically nor dermatopathologically. It may well be that linear atrophoderma of Moulin and zosteriform or linear scleroderma belong to the spectrum of a single disease.

With the growing literature it has been demonstrated that age of onset is not limited to childhood or adolescence. The disease may also present later in life. Lesions are not always unilateral. They may be bilateral but in a linear distribution along Blaschko's lines (Table 1). Distribution mainly along the Blaschko lines reflects mosaicism.

Dermatopathologic findings of linear atrophoderma of Moulin vary. The epidermis is normal in the majority of cases. However, in two reports there was vacuolar degenera-

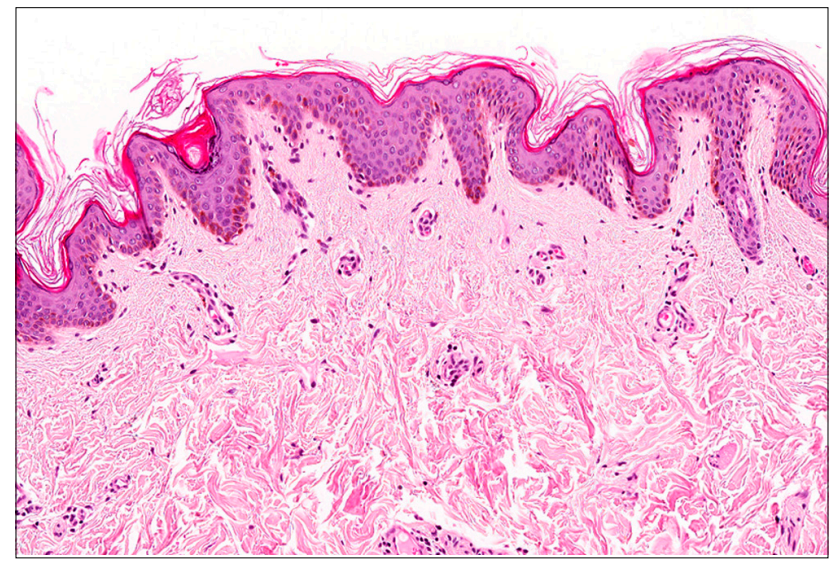

Figure 3. Normal epidermis with hyperpigmented basal layer. [Copyright: @2013 Patsatsi et al.]

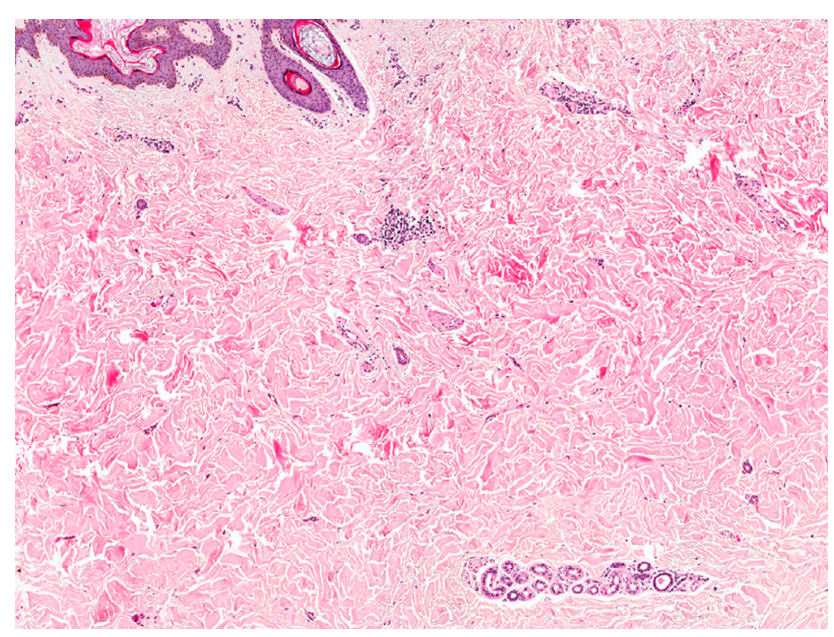

Figure 4. Thickened collagen fibers in the dermis. [Copyright: $@ 2013$ Patsatsi et al.]

tion of the basement membrane [2,7]. Few reports suggest an inflammatory early stage is suggested. The question of a transient inflammatory early stage that is no longer present by the time of clinical evaluation and biopsy remains.

Although the alteration of the connective tissue is not described in the original paper, most of the reviewed papers describe an increase of collagen. Unaltered, fragmented or decreased collagen fibers have been also reported in isolated cases, as well as edema of the dermis (Table 1). Another issue that has not been addressed is the cause of the clinical presentation of atrophic plaques. Does the loss of subcutaneous fat result in atrophy?

In conclusion, even now, 20 years after the first description of atrophoderma of Moulin this rare disease is puzzling. It seems to occur at any age. It is characterized clinically by the presence of atrophic patches distributed along Blaschko lines and dermatopathologically by a normal epidermis with a hyperpigmented basal layer, a dermis with thickened collagen fibers and loss of subcutaneous fat. Etiology and pathogenesis of this disease remains still unclear. 
TABLE 1. Reported cases of linear atrophoderma of Moulin

\begin{tabular}{|c|c|c|c|c|c|}
\hline Cases & $\begin{array}{l}\text { Case } \\
\text { no. }\end{array}$ & $\begin{array}{l}\text { Age at } \\
\text { presen- } \\
\text { tation/ } \\
\text { sex }\end{array}$ & Area of involvement & $\begin{array}{l}\text { Disease } \\
\text { duration } \\
\text { when } \\
\text { reported }\end{array}$ & Histological findings \\
\hline $\begin{array}{l}\text { Moulin } 1992,1 \text { st of } 5 \\
\text { cases [1] }\end{array}$ & 1 & $8 / \mathrm{M}$ & Left side of trunk & & \\
\hline $\begin{array}{l}\text { Moulin 1992, 2nd of } 5 \\
\text { cases [1] }\end{array}$ & 2 & $7 / \mathrm{F}$ & Right side of trunk & & \\
\hline $\begin{array}{l}\text { Moulin 1992, 3rd of } 5 \\
\text { cases [1] }\end{array}$ & 3 & $15 / \mathrm{M}$ & Right side of trunk & & \\
\hline $\begin{array}{l}\text { Moulin } 1992,4 \text { th of } 5 \\
\text { cases [1] }\end{array}$ & 4 & $20 / \mathrm{M}$ & Left side of trunk & & \\
\hline $\begin{array}{l}\text { Moulin } 1992,5 \text { th of } 5 \\
\text { cases [1] }\end{array}$ & 5 & $6 / \mathrm{M}$ & Left arm and trunk & & \\
\hline Baumann et al 1994 [2] & 6 & $22 / \mathrm{M}$ & Right arm and trunk & & $\begin{array}{l}\text { Ballooning in basal } \\
\text { epidermis (?), increased col- } \\
\text { lagen in dermis }\end{array}$ \\
\hline $\begin{array}{l}\text { Braun RP, Saurat JH, } \\
1996[3]\end{array}$ & 7 & $16 / \mathrm{M}$ & $\begin{array}{l}\text { Left side of back, left } \\
\text { side of abdominal area }\end{array}$ & & \\
\hline $\begin{array}{l}\text { Wollenberg A et al, } 1996 \\
\text { [4] }\end{array}$ & 8 & $5 / \mathrm{F}$ & Right arm/ trunk & 17 & $\begin{array}{l}\text { Epidermal atrophy, in- } \\
\text { creased collagen in dermis }\end{array}$ \\
\hline $\begin{array}{l}\text { Artola Igarza JL et al, } \\
1996 \text { [5] }\end{array}$ & 9 & $16 / \mathrm{F}$ & Left part of the trunk & & $\begin{array}{l}\text { Increased collagen in the } \\
\text { dermis }\end{array}$ \\
\hline $\begin{array}{l}\text { Cecchi and Giomi, } 1997 \\
\text { [6] }\end{array}$ & 10 & $12 / \mathrm{F}$ & Right arm and back & & $\begin{array}{l}\text { Hyperpigmentation in the } \\
\text { basal layer of the epidermis }\end{array}$ \\
\hline Rompel R et al, 2000 [7] & 11 & $17 / F$ & $\begin{array}{l}\text { Right side of the trunk, } \\
\text { right buttock }\end{array}$ & & $\begin{array}{l}\text { Focal vacuolar degenera- } \\
\text { tion of the basal layer, in- } \\
\text { creased collagen in dermis }\end{array}$ \\
\hline Browne C et al, 2000 [8] & 12 & $10 / \mathrm{M}$ & $\begin{array}{l}\text { Trunk and limbs, } \\
\text { bilateral }\end{array}$ & 6 & $\begin{array}{l}\text { Slightly thinned epidermis } \\
\text { with prominent blood ves- } \\
\text { sels, slight increase in the } \\
\text { amount of collagen }\end{array}$ \\
\hline Martin et al 2002 [9] & 13 & $9 / \mathrm{M}$ & Left side of trunk & & Increased collagen \\
\hline Miteva L et al, 2002 [10] & 14 & $20 / \mathrm{F}$ & $\begin{array}{l}\text { Right arm, buttock } \\
\text { and leg }\end{array}$ & 4 years & Increased collagen \\
\hline Utikal et al, 2003 [11] & 15 & 29/M & $\begin{array}{l}\text { Limbs and trunk, } \\
\text { bilateral }\end{array}$ & 6 years & Slight edema of the dermis \\
\hline Utikal et al, 2003 [11] & 16 & $15 / \mathrm{F}$ & $\begin{array}{l}\text { Limbs and trunk, } \\
\text { bilateral }\end{array}$ & 13 years & Slight edema of the dermis \\
\hline $\begin{array}{l}\text { Danarti et al, } 2003 \\
\text { (1st of } 4 \text { cases) [12] }\end{array}$ & 17 & $14 / \mathrm{F}$ & Left side of the body & 1 year & $\begin{array}{l}\text { Perivascular lymphocytic } \\
\text { infiltrate }\end{array}$ \\
\hline $\begin{array}{l}\text { Danarti et al, } 2003 \\
\text { (2nd of } 4 \text { cases) [12] }\end{array}$ & 18 & $24 / \mathrm{F}$ & $\begin{array}{l}\text { Left side of her abdo- } \\
\text { men and her back, left } \\
\text { arm }\end{array}$ & & Biopsy not performed \\
\hline $\begin{array}{l}\text { Danarti et al, (3rd of } 4 \\
\text { cases) [12] }\end{array}$ & 19 & $38 / \mathrm{F}$ & Left medial thigh & 1.6 year & $\begin{array}{l}\text { Unremarkable epidermis } \\
\text { and dermis }\end{array}$ \\
\hline
\end{tabular}


TABLE 1. (continued)

\begin{tabular}{|c|c|c|c|c|c|}
\hline Cases & $\begin{array}{l}\text { Case } \\
\text { no. }\end{array}$ & $\begin{array}{l}\text { Age at } \\
\text { presen- } \\
\text { tation/ } \\
\text { sex }\end{array}$ & Area of involvement & $\begin{array}{l}\text { Disease } \\
\text { duration } \\
\text { when } \\
\text { reported }\end{array}$ & Histological findings \\
\hline $\begin{array}{l}\text { Danarti et al, 2003, } \\
\text { (4th of } 4 \text { cases) [12] }\end{array}$ & 20 & $15 / \mathrm{F}$ & $\begin{array}{l}\text { Left side on the } \\
\text { buttock and on her } \\
\text { lateral iliac crest along } \\
\text { Blaschko's lines }\end{array}$ & 1 year & Biopsy not performed \\
\hline Miteva L et al 2005 [13] & 21 & $9 / \mathrm{M}$ & $\begin{array}{l}\text { Left side of the trunk, } \\
\text { left upper limb }\end{array}$ & 5 years & Increased collagen \\
\hline $\begin{array}{l}\text { Atasoy } \mathrm{M} \text { et al, } 2006 \\
{[14]}\end{array}$ & 22 & $16 / \mathrm{M}$ & $\begin{array}{l}\text { Right side of the trunk, } \\
\text { right arm }\end{array}$ & 2 years & $\begin{array}{l}\text { Epidermal atrophy, frag- } \\
\text { mented collagen fibers }\end{array}$ \\
\hline $\begin{array}{l}\text { Zampetti A et al, } 2008 \\
{[15]}\end{array}$ & 23 & $37 / \mathrm{F}$ & Left arm and trunk & 5 years & $\begin{array}{l}\text { Hyperpigmentation of } \\
\text { epidermal basal cells, slight } \\
\text { thickening of the collagen } \\
\text { fibers in the mid-deep } \\
\text { dermis }\end{array}$ \\
\hline Gecchi et al, 2008 [16] & 24 & $9 / \mathrm{M}$ & $\begin{array}{l}\text { Exclusive involvement } \\
\text { of the neck }\end{array}$ & 1 year & $\begin{array}{l}\text { A normal epidermis with } \\
\text { moderate, diffuse hyperpig- } \\
\text { mentation of the basal layer } \\
\text { A perivascular lymphocytic } \\
\text { infiltrate was noted in the } \\
\text { dermis, without any other } \\
\text { pathologic feature }\end{array}$ \\
\hline Lopez N et al, 2008 [17] & 25 & $17 / \mathrm{M}$ & Right upper arm & 1 year & $\begin{array}{l}\text { Localized hyperpigmenta- } \\
\text { tion in the basal layer of } \\
\text { the epidermis }\end{array}$ \\
\hline $\begin{array}{l}\text { Ozkaya E et al, } 2010 \\
{[18]}\end{array}$ & 26 & $18 / \mathrm{F}$ & $\begin{array}{l}\text { Legs, arms and trunk } \\
\text { including the axillary } \\
\text { regions }\end{array}$ & 1 year & $\begin{array}{l}\text { Slight epidermal acanthosis, } \\
\text { a slightly hyperpigmented } \\
\text { basal layer, and a slight } \\
\text { decrease in elastic fibers in } \\
\text { papillary dermis }\end{array}$ \\
\hline Ripert C et al, 2010 [19] & 27 & $14 / \mathrm{F}$ & Left side of trunk & $\begin{array}{l}15 \\
\text { months }\end{array}$ & $\begin{array}{l}\text { Dermal atrophy with pig- } \\
\text { mentation of the basal layer } \\
\text { and a perivascular lympho- } \\
\text { cytic infiltrate }\end{array}$ \\
\hline $\begin{array}{l}\text { Schepis C et al, } 2010 \\
{[20]}\end{array}$ & 28 & $14 / \mathrm{M}$ & Left side of trunk & $\begin{array}{l}\text { A few } \\
\text { months }\end{array}$ & $\begin{array}{l}\text { A hyperpigmented basal } \\
\text { layer } \\
\text { In the upper dermis, dilated } \\
\text { superficial vessels were } \\
\text { visible } \\
\text { The mid and deep dermis } \\
\text { were mildly edematous }\end{array}$ \\
\hline
\end{tabular}

(Continued next page) 
TABLE 1. (continued)

\begin{tabular}{|l|c|c|l|l|l|}
\hline Cases & $\begin{array}{c}\text { Case } \\
\text { no. }\end{array}$ & $\begin{array}{c}\text { Age at } \\
\text { presen- } \\
\text { tation/ } \\
\text { sex }\end{array}$ & Area of involvement & $\begin{array}{c}\text { Disease } \\
\text { duration } \\
\text { when } \\
\text { reported }\end{array}$ & \multicolumn{1}{|c|}{ Histological findings } \\
\hline $\begin{array}{l}\text { Tukenmez Demirci G et } \\
\text { al, 2011 [21] }\end{array}$ & 29 & $39 / \mathrm{F}$ & Left half of the neck & 22 years & $\begin{array}{l}\text { A normal epidermis out- } \\
\text { lined by a hyperpigmented- } \\
\text { basal layer } \\
\text { In the papillary dermis pro- } \\
\text { liferation of superficial ves- } \\
\text { sels with mild lymphocytic } \\
\text { infiltrate and melanin-laden } \\
\text { macrophages were present } \\
\text { Collagen fibers and elastic } \\
\text { fibers were normal }\end{array}$ \\
\hline $\begin{array}{l}\text { Norisugi O et al, 2011 } \\
\text { 22] }\end{array}$ & 30 & $26 / \mathrm{M}$ & $\begin{array}{l}\text { Right side of trunk, } \\
\text { posterior right leg }\end{array}$ & 1 year & $\begin{array}{l}\text { Thickness of the subcutane- } \\
\text { ous tissue was reduced in } \\
\text { lesional skin compared to } \\
\text { normal skin by ultrasound } \\
\text { examination }\end{array}$ \\
\hline Our case & 31 & $17 / \mathrm{F}$ & Left side of trunk & 6 months & $\begin{array}{l}\text { Thin epidermis, hyper- } \\
\text { pigmentation of the basal } \\
\text { layer, increased collagen } \\
\text { fibers, rather thin subcutis }\end{array}$ \\
\hline
\end{tabular}

\section{References}

1. Moulin G, Hill MP, Guillaud V, Barrut D, Chevallier J, Thomas L. Acquired atrophic pigmented band-like lesions following Blaschko's lines. Ann Dermatol Venereol. 1992;119(10):729-36.

2. Baumann L, Happle R, Plewig G, Schirren CG. [Atrophodermia linearis Moulin. A new disease picture, following the Blaschko lines.] [Article in German] Hautarzt. 1994;45(4):231-6.

3. Braun RP, Saurat JH. A case of linear atrophoderma of Moulin. J Dermatol. 1996;23(9):660.

4. Wollenberg A, Baumann L, Plewig G. Linear atrophoderma of Moulin: a disease which follows Blaschko's lines. Br J Dermatol. 1996;135(2):277-9.

5. Artola Igarza JL, Sánchez Conejo-Mir J, Corbí Llopis MR, et al. Linear atrophoderma of Moulin: treatment with Potaba. Dermatology. 1996;193(4):345-7.

6. Cecchi R, Giomi A. Linear atrophoderma of Moulin. Acta Derm Venereol. 1997;77(6):485.

7. Rompel R, Mischke AL, Langner C, Happle R. Linear atrophoderma of Moulin. Eur J Dermatol. 2000;10(8):611-3.

8. Browne C, Fisher BK. Atrophoderma of moulin with preceding inflammation. Int J Dermatol. 2000;39(11):850-2.

9. Martin L, Georgescu V, Nizard S, Happle R, Estève E. [Unilateral atrophoderma following Blaschko's lines: Blaschkolinear morphoea or Moulin's linear atrophoderma?] [Article in French]. Ann Dermatol Venereol. 2002;129(4 Pt 1):431-2.

10. Miteva L, Obreshkova E. An unusual manifestation of linear atrophoderma of Moulin. Acta Derm Venereol. 2002;82(6):479-80.

11. Utikal J, Keil D, Klemke CD, Bayerl C, Goerdt S. Predominant telangiectatic erythema in linear atrophoderma of Moulin: novel variant or separate entity? Dermatology. 2003;207(3):310-5.

12. Danarti R, Bittar M, Happle R, K冈nig A. Linear atrophoderma of Moulin: postulation of mosaicism for a predisposing gene. J Am Acad Dermatol. 2003; 49(3):492-8.
13. Miteva L, Nikolova K, Obreshkova E. Linear atrophoderma of Moulin. Int J Dermatol. 2005;44(10):867-9.

14. Atasoy M, Aliagaoglu C, Sahin O, Ikbal M, Gursan N. Linear atrophoderma of Moulin together with leuconychia: a case report. J Eur Acad Dermatol Venereol. 2006;20(3):337-40.

15. Zampetti A, Antuzzi D, Caldarola G, Caldarola G, Celleno L, Amerio P, Feliciani C. Linear atrophoderma of Moulin. Eur J Dermatol. 2008;18(1):79-80.

16. Cecchi R, Bartoli L, Brunetti L, Pavesi M. Linear atrophoderma of Moulin localized to the neck. Dermatol Online J. 2008;14(6):12.

17. López N, Gallardo MA, Mendiola M, Bosch R, Herrera E. [A case of linear atrophoderma of Moulin]. Article in Spanish. Actas Dermosifiliogr. 2008;99(2):165-7.

18. Özkaya E, Yazgano囚lu KD. Lentiginosis within plaques of linear atrophoderma of Moulin: a twin-spotting phenomenon? $\mathrm{Br} \mathrm{J}$ Dermatol. 2010;163(5):1138-40.

19. Ripert C, Vabres P. Linear atrophoderma of moulin associated with antinuclear antibodies. J Eur Acad Dermatol Venereol. 2010;24(1):108-9.

20. Schepis C, Palazzo R, Lentini M. A teen-ager with linear atrophoderma of Moulin. Dermatol Online J. 2010;16(2):7.

21. Tukenmez Demirci G, Altunay IK, Mertoglu E, Kucukunal A, Sakiz D. Linear atrophoderma of Moulin on the neck. J Dermatol Case Rep. 2011;5(3):47-9.

22. Norisugi O, Makino T, Hara H, Matsui K, Furuichi M, Shimizu T. Evaluation of skin atrophy associated with linear atrophoderma of Moulin by ultrasound imaging. J Am Acad Dermatol. 2011;65(1):232-3.

23. Ang GC, Lee JB. Linear atrophoderma of Moulin: is it a single disease? J Am Acad Dermatol. 2005;52(5):923-4. 